\title{
RATIONALE FOR RELEASE OF THE IRISH STRAIN OF MICROCTONUS AETHIOPOIDES FOR BIOCONTROL OF CLOVER ROOT WEEVIL
}

\author{
P.J. GERARD ${ }^{1}$, M.R. McNEILL ${ }^{2}$, B.I.P. BARRATT ${ }^{3}$ \\ and S.A. WHITEMAN ${ }^{4}$ \\ ${ }^{1}$ AgResearch, Ruakura Research Centre, Private Bag 3123, Hamilton, \\ New Zealand \\ ${ }^{2}$ AgResearch, PO Box 60, Lincoln, New Zealand \\ ${ }^{3}$ AgResearch, Invermay Research Centre, Private Bag 50034, Mosgiel, \\ New Zealand \\ ${ }^{4}$ ERMA New Zealand, PO Box 131, Wellington, New Zealand \\ Corresponding author: pip.gerard@agresearch.co.nz
}

\begin{abstract}
A European biotype of Microctonus aethiopoides was identified as the best candidate biocontrol agent for Sitona lepidus, a serious New Zealand pasture pest. A Moroccan biotype was already present throughout the country and hence there was no requirement to obtain Hazardous Substances and New Organisms (HSNO) Act approval to release new biotypes. However, as research had shown mating between the two biotypes produced hybrids with poor efficacy against target hosts, and that the Moroccan biotype attacked several native weevil genera, serious reservations were held about introducing the European biotype. Concerns were overcome with the identification of a parthenogenetic strain of European $M$. aethiopoides from Ireland, which has little risk of hybridisation, and a narrower host range than the Moroccan biotype. Following regulation of $M$. aethiopoides as a risk species, this strain was considered to be a new organism. Approval was sought and gained under the HSNO Act to release the strain.

Keywords: Microctonus aethiopoides, Sitona lepidus, Environmental Risk Management Authority, biocontrol.
\end{abstract}

\section{INTRODUCTION}

When clover root weevil (CRW) (Sitona lepidus Gyllenhal (Coleoptera: Curculionidae)) was first discovered in 1996, it was anticipated that two weevil parasitoids already present in New Zealand pastures, namely the braconids Microctonus aethiopoides Loan and $M$. hyperodae Loan, might provide at least partial control of CRW (Barratt et al. 1996). At that time the Moroccan biotype of M. aethiopoides, introduced in 1982 (Stufkens et al. 1987), was providing effective control for the lucerne pest Sitona discoideus Gyllenhal (Goldson et al. 2005), and a single specimen of M. hyperodae had been reared from CRW collected from the Ruakura Research Centre dairy farm (Barratt et al. 1996) where this parasitoid had been released in 1991. However, this hope was unfounded. Less than ten $M$. aethiopoides were reared from field collections over the following 10 years, and CRW rapidly became one of the most damaging clover pests found in New Zealand. Furthermore, laboratory tests confirmed that neither the Moroccan biotype of $M$. aethiopoides nor $M$. hyperodae were effective against CRW (Barratt et al. 1997b).

White clover (Trifolium repens L.) is a high value component of most pastures in New Zealand (Caradus et al. 1996). With a potential annual direct cost of the pest estimated 
at $\$ 300$ million a year (Barlow \& Goldson 2002), the pastoral industry looked to the research community for solutions. With in-depth knowledge of weevil biology and control, AgResearch entomologists advocated the introduction of a biocontrol agent as a potential long-term solution to CRW that could be implemented without changing existing on-farm management systems.

\section{SUMMARY OF THE SEARCH FOR A BIOLOGICAL CONTROL AGENT}

The project commenced in 1998, initially in collaboration with CABI Bioscience Centre for exploration in Switzerland, and with the University of California, Berkley, USA, for searches in California and Oregon (Phillips et al. 2000). Progress was very slow until the European exploration was expanded with AgResearch entomologists setting up temporary research bases in France in 1999-2000 (Phillips et al. 2002) and subsequently in England in 2000 (Goldson et al. 2004). Collaboration with researchers undertaking comparative white clover field trials across Europe greatly facilitated the search, with weevil samples being forwarded from Italy, Romania, France, Netherlands, Norway, Finland and Sweden, and further collections undertaken by AgResearch staff in Ireland, Wales, England and Scotland (Goldson et al. 2004).

The parasitoids found were the braconids M. aethiopoides, an unidentified Allurus sp., Allurus lituratus Haliday and Perilitus sp., and the tachanid Microsoma exiguum Meigen (Goldson et al. 2004). Of these, M. aethiopoides was by far the most commonly recovered, both within and between countries, and had the highest rates of parasitism in laboratory tests compared to the other parasitoids recovered (Phillips et al. 2002; Goldson et al. 2004). In contrast to the Moroccan biotype of $M$. aethiopoides introduced to control $S$. discoideus, the European biotype showed excellent efficacy against New Zealand CRW. For these reasons the European M. aethiopoides was selected for further investigation.

Cultures of the European biotype from six countries were established in quarantine in New Zealand in late 2000 and research commenced to investigate suitability for introduction (Goldson et al. 2001). It was found that hybridisation between the European and Moroccan biotypes led to significant reductions in efficacy of $M$. aethiopoides against both CRW and S. discoideus (Goldson et al. 2003). This was a major set back but was overcome with the serendipitous discovery of an all-female strain of the European biotype in Ireland that reproduced by thelytokous parthenogeneticity and was effective against CRW (Goldson et al. 2005). Microctonus aethiopoides reared from subsequent collections throughout Ireland have all been parthenogenetic and molecular techniques have shown that this strain can be distinguished from other strains within the European biotype (Vink et al. 2003).

\section{SUMMARY OF EFFICACY AND HOST TESTING}

The Moroccan biotype of $M$. aethiopoides parasitises a number of indigenous and exotic non-target genera in the field (Barratt 2004), especially broad-nosed weevils in the subfamily Entiminae (subfamily classification of Leschen et al. 2003). While there is no evidence of an adverse impact on these weevil populations, the knowledge of this unexpected wide host range contributed to increased concern in New Zealand about the potential impacts of all new biological control agents on non-target species (e.g. Barratt et al. 2000), let alone a new M. aethiopoides biotype.

The host range testing of the Irish strain is summarised by Goldson et al. (2005). Representatives of the weevil genera attacked by the Moroccan biotype were tested in a series of no-choice and choice tests. It was found that the Irish strain was more selective and, with the exception of Nicaeana cervina Broun, had lower parasitism rates than its Moroccan counterpart. It is possible that the difference in attack rates may be associated with the virus-like particles which are present in Moroccan (Barratt et al. 1999) but not the Irish M. aethiopoides (Barratt et al. 2006). These particles may be important in the 
suppression of the host weevil's immune defence system and allow a wider host range. Of the species tested, only Irenimus aequalis Broun and N. cervina are considered likely to act as hosts to the new strain, and both species are preferred less than CRW by Irish $M$. aethiopoides and had higher levels of non-viable parasitoid larvae.

In the host range studies, attack rates of the Irish biotype of $M$. aethiopoides on CRW averaged over 70\% (Goldson et al. 2005). Comparative levels of 67\% parasitism were achieved during similar laboratory testing of $M$. hyperodae against Listronotus bonariensis (Kuschel) prior to release (Barratt et al. 1997a) and this Microctonus species subsequently reduced host weevil populations in the field (e.g. Goldson et al. 1998).

\section{HSNO ACT APPROVAL PROCESS}

Under the Hazardous Substances and New Organisms (HSNO) Act 1996 a number of criteria define a new organism, the most relevant being an "An organism belonging to a species that was not present in New Zealand immediately before 29 July 1998". With the Moroccan biotype already established in New Zealand, there was no need to obtain a HSNO Act approval to release the Irish strain. However, concerns about possible hybridization and known differences in host range suggested that a cautious approach should be taken. Because of this concern, at AgResearch's request, in December 2004 the Minister for the Environment prescribed M. aethiopoides to be a 'risk species'. As a result all strains, with the exception of the Moroccan biotype, are considered to be 'new organisms' and as such require a HSNO Act approval. HSNO Act approvals are obtained following a risk assessment by the Environmental Risk Management Authority (ERMA New Zealand). Microctonus aethiopoides is widely distributed in the Northern Hemisphere with different biotypes and strains, each adapted to a different set of hosts (Aeschlimann 1995).

Obtaining HSNO Act approval was facilitated considerably by discussion and advice from ERMA New Zealand, and information available on previous release applications for biological control agents. AgResearch applied for conditional rather than full release approval to allow restriction of the approval to the thelytokous parthenogenetic Irish strain only. In this way the potential adverse effects associated with hybridisation of other M. aethiopoides strains with the Moroccan biotype and loss of control of $S$. discoideus could be mitigated. AgResearch proposed, and ERMA New Zealand agreed to, a method to test new populations in containment to verify that individuals are thelytokous parthenogenetic.

Consultation with the Maori community was initiated as soon as confirmation was received that release required HSNO Act approval. Following advice from the Maori Unit at ERMA New Zealand, letters outlining the details of the proposal, and including postage-free response forms, were sent to 82 Iwi throughout New Zealand in December 2004. Subsequently, information folders (including a handout in Maori showing the life cycles of the parasitoid and weevil) were sent to the 13 Iwi that requested further details or expressed interest. AgResearch contracted Indigenous Corporate Solutions (IC Solutions) to facilitate and report on meetings with interested Iwi, which fostered useful open and friendly discussion.

As required under the HSNO Act the application was publicly notified. A total of 10 public submissions were received, six in support, three neutral or 'not opposed' and one from a private citizen opposing the release of the Irish parasitoid. Two of the submitters supporting the application presented their submissions at the public hearing on 12 October 2005. Following a risk assessment in which the benefits of releasing the Irish parthenogenetic strain were found to outweigh the risks and costs, the Authority approved the release, with controls for any future importations of the parasitoid.

The application was submitted on 23 May 2005 and approval was granted on 8 November 2005. The first release of the parasitoid was made on a farm near Morrinsville on 5 January 2006, with further releases in Hawke's Bay and Manawatu over the following six weeks. Establishment at the Hawke's Bay release site was confirmed by early April. 
Ongoing research will monitor the buildup and spread of the parasitoid while native and introduced beneficial weevil species at the release sites will be sampled regularly to detect any parasitism of non-target species.

\section{ACKNOWLEDGEMENTS}

The authors wish to thank the many people that contributed to and supported us with the application. The biocontrol programme has had a number of funders since 1998, the key contributors being New Zealand Foundation for Research, Science and Technology, Dairy Insight and Meat \& Wool New Zealand.

\section{REFERENCES}

Aeschlimann J-P 1995. Lessons from post-release investigations in classical biological control: the case of Microctonus aethiopoides Loan (Hym., Braconidae) introduced into Australia and New Zealand for the biological control of Sitona discoideus Gyllenhal (Col., Curculionidae). In: Hokkanen HMT, Lynch JM ed. Biological Control: Benefits and Risks. Cambridge University Press, New York. Pp. 75-83.

Barlow ND, Goldson SL 2002. Alien invertebrates in New Zealand. In: Pimental D ed. Biological Invasions: economic and environmental costs of alien plant, animal, and microbe species. CRC Press, New York, USA. Pp. 195-216.

Barratt BIP, Evans AA, Ferguson CM, Barker GM, McNeill MR, Phillips CB 1997a. Laboratory nontarget host range of the introduced parasitoids Microctonus aethiopoides and Microctonus hyperodae (Hymenoptera: Braconidae) compared with field parasitism in New Zealand. Environmental Entomology 26: 694-702.

Barratt BIP, Evans AA, Ferguson CM 1997b. Potential for control of Sitona lepidus Gyllenhal by Microctonus spp. New Zealand Plant Protection 50: 37-40.

Barratt BIP, Evans AA, Stoltz DB, Vinson SB, Easingwood R 1999. Virus-like particles in the ovaries of Microctonus aethiopoides Loan (Hymenoptera: Braconidae), a parasitoid of adult weevils (Coleoptera: Curculionidae). Journal of Invertebrate Pathology 73: 182-188.

Barratt BIP, Barker GM, Addison PJ 1996. Sitona lepidus Gyllenhal (Coleoptera: Curculionidae), a potential clover pest new to New Zealand. New Zealand Entomologist 19: 23-30.

Barratt BIP, Goldson SL, Ferguson CM, Phillips CB, Hannah DJ 2000. Predicting the risk from biological control agent introductions: A New Zealand approach. In: Follett PA, Duan JJ ed. Nontarget effects of biological control introductions. Kluwer Academic Publishers, Norwell, Massachusetts, USA. Pp. 59-75.

Barratt BIP 2004. Microctonus parasitoids and New Zealand weevils: comparing laboratory estimates of host ranges to realized host ranges. In: Van Driesche RG, Reardon R ed. Assessing host ranges for parasitoids and predators used for classical biological control: A guide to best practice. USDA Forest Service, Morgantown, West Virginia. Pp. 103-120.

Barratt BIP, Murney R, Easingwood R, Ward VK 2006. Virus-like particles in the ovaries of Microctonus aethiopoides Loan (Hymenoptera: Braconidae): comparison of biotypes from Morocco and Europe. Journal of Invertebrate Pathology 91:13-18.

Caradus JR, Woodfield DR, Stewart AV 1996. Overview and vision for white clover. Agronomy Society of New Zealand Special Publication 11. Grassland Research and Practice Series 6: 1-6.

Goldson SL, McNeill MR, Gerard PJ, Proffitt JR, Phillips CB, Cane RP, Murray PJ 2004. British-based search for natural enemies of the clover root weevil, Sitona lepidus in Northwest Europe. New Zealand Journal of Zoology 31: 233-240.

Goldson SL, McNeill MR, Proffitt JR, Barratt BIP 2005. Host specificity testing and suitability of a European biotype of the braconid parasitoid Microctonus aethiopoides Loan as a biological control agent against Sitona lepidus (Coleoptera: Curculionidae) in New Zealand. Biocontrol Science \& Technology 15: 791-813. 
Goldson SL, McNeill MR, Proffitt JR 2003. Negative effects of strain hybridisation on the biocontrol agent Microctonus aethiopoides. New Zealand Plant Protection 56: $138-142$.

Goldson SL, Phillips CB, McNeill MR, Proffitt JR, Cane RP 2001. Importation to New Zealand quarantine of a candidate biological control agent of clover root weevil. New Zealand Plant Protection 54: 147-151.

Goldson SL, Proffitt JR, Baird DB 1998. Establishment and phenology of the parasitoid Microctonus hyperodae Loan in New Zealand. Environmental Entomology 27: 1386-1392.

Leschen AB, Lawrence JF, Kuschel G, Thorpe S, Wang Q 2003. Coleoptera genera of New Zealand. New Zealand Entomologist 26: 15-28.

McNeill MR, Proffitt JR, Gerard PJ, Goldson SL 2006. Collections of Microctonus aethiopoides Loan (Hymenoptera: Braconidae) from Ireland. New Zealand Plant Protection 59: 290-296.

Phillips CB, Goldson SL, Reimer L, Kuhlmann U 2000. Progress in the search for biological control agents of clover root weevil, Sitona lepidus (Coleoptera: Curculionidae). New Zealand Journal of Agricultural Research 43: 541-547.

Phillips CB, Cane, RP, Mee J, Chapman HM, Hoelmer KA, Coutinot D 2002. Intraspecific variation in the ability of Microctonus aethiopoides (Hymenoptera: Braconidae) to parasitise Sitona lepidus (Coleoptera: Curculionidae). New Zealand Journal of Agricultural Research 45: 295-303.

Stufkens, MW, Farrell JA, Goldson SL 1987. Establishment of Microctonus aethiopoides a parasitoid of the sitona weevil in New Zealand. Proceedings of the 40th New Zealand Weed and Pest Control Conference: 31-32.

Vink CJ, Phillips CB, Mitchell AD, Winder LM, Cane RP 2003. Genetic variation in Microctonus aethiopoides (Hymenoptera: Braconidae). Biological Control 28: 251-264. 